\title{
Grammatical Error Made by EFL Learners of STIBA Persada Bunda in Thesis Proposal
}

\author{
Maspufah \\ Akademi Bahasa Asing Persada Bunda \\ E-mail: maspufah81@gmail.com
}

\begin{abstract}
Writing is regarded as one of difficult skill in learning English because it needs more effort to elaborate a complex process of generating, organizing, and revising ideas on a paper. Since English is not students' mother tongue, error might be occurred in their writing. This research was intended to identify the types and the causes of error made by EFL learners of STIBA Persada Bunda in thesis proposal. It was a descriptive research. Thirteen students from the eighth semester of 2018-2019 academic years were taken for the sample. The instruments used to collect the data were in quantitative and qualitative form. Students' thesis proposals were taken for quantitative data. Interview was used for qualitative data. The result showed that there were four types of grammatical error found in EFL learners' thesis proposal: addition, omission, misformation, and misordering. The Errors in their thesis proposal were caused by three conditions: inter-lingual, intra-lingual, and communication strategy-based error. Inter-lingual occurred because of first language interfere when transferring from first language to target lnguage. Intra-lingual occurred in the incomplete rule application and exploiting redundancy. Avoidance caused communication strategy-based error. It could be concluded that EFL learners' competence in writing needed to be improved as there were many grammatical errors occurred in their thesis proposal.
\end{abstract}

Keywords: Grammar, Writing, Grammatical Error

\section{Kesalahan Tata Bahasa dalam Proposal Skripsi oleh Mahasiswa EFL STIBA Persada Bunda}

\begin{abstract}
Abstrak
Menulis dianggap sebagai salah satu keterampilan yang sulit dalam mempelajari bahasa Inggris karena membutuhkan usaha keras dalam proses mencari idea, menyusun, dan memperbaiki ide secara tertulis. Karena bahasa inggris bukan bahasa Ibu, kesalahan mungkin terjadi dalam karya tulis mahasiswa. Penelitian ini bertujuan untuk mengidentifikasi jenis dan penyebab kesalahan yang terjadi pada proposal skripsi mahasiswa EFL STIBA Persada Bunda. Penelitian ini merupakan penelitian desktiptif. Sampel penelitian ini adalah 13 orang mahasiswa semester delapan tahun ajaran 20182019. Penelitian ini menggunakan dua instrument untuk mengumpulkan data yaitu instrument kuantitatif dan kualitatif. Proposal skripsi mahasiswa digunakan sebagai
\end{abstract}


sumber data kuantitatif dan wawancara digunakan sebagai sumber data kualitatif. Setelah menganalisi data ditemukan bahwa ada empat jenis kesalahan yang ditemukan dalam proposal skripsi mahasiswa yaitu addition, omission, misformation, dan misordering. Selain itu ada tiga penyebab kesalahan pada penelitian ini yaitu inter-lingual, intra-lingual dancommunication strategy-based error. inter-lingualterjadi karena pengaruh bahasa pertama ketika ditransfer ke bahasa kedua. Intra-lingual terjadi karena penggunaan tata bahasa yang tidak sempurna dan terjadinya rendundansi. Communication based strategy based error terjadi karena avoidance. Oleh karena itu dapat disimpulkan bahwa kompetensi mahasiswa dalam menulis masih perlu ditingkatkan karena masih banyak kesalahan penggunaan tatabahasa dalam proposal skripsi mereka.

Kata Kunci : Tata Bahasa, Menulis, Kesalahan Tata Bahasa

\section{INTRODUCTION}

Writing is regarded as one of difficult skill out of other English basic skills: listening, speaking, and reading. It needs more effort to elaborate a complex process of generating, organizing, and revising ideas on a paper. The idea should be organized in such a way logically and understandably. So, the idea conveyed through the writing will be delivered well to the readers.

As English Foreign Language (EFL) learners, students of Sekolah Tinggi Ilmu Bahasa Asing (STIBA) Persada Bunda needs to learn writing. Writing is an artificial activity which requires conscious learning or efforts to be able to acquire the activity. Principally writing aims at expressing ideas and conveying messages to reader (Ur cited in Gusparia, 2014:36). Furthermore, students are required to make a research paper to accomplish the degree. To meet the requirement, students get three semesters of learning writing. It is also enriched by supplementary lectures which support their capability in writing students are demanded to have a good competence in delivering their ideas in composing their thesis at the end of their college period.
Delivering idea in a good writing of formal English is not easy for EFL learners. Since English is not their mother tongue, error might be occurred in their writing. Error is the deviation of learner speech or writing from several selected norm of Standard English (Dulay, Burt, and Krashen, cited in Ahmad 2014: 13) Furthermore, they also classified error into four categories. For EFL learners, the errors commonly occurred in constructing sentence in such as addition, omission, misformation, and misordering

Based on her experience in teaching writing in STIBA Persada Bunda, the writer found the common problems faced by students due to several factors. First, most of them found difficulty in choosing the appropriate word to deliver their idea as there are many words in English have similar meaning. Inability to choose the appropriate vocabulary may lead the reader to have misperception or misunderstanding with the topic discussed. Second, students had difficulties to use the correct grammar. They tent to make error in using tenses, concordance, active and passive sentence, article, and punctuation usage. The errors in using grammar made 
the sentences were mess. The incorrect grammar used also made the idea did not delivered correctly and accurately.

In writing their idea, learners need to understand the aspects of writing. It requires complex skills which include some elements. One of the elements that can be mentioned is the use of grammar. Grammar is not only important in arranging the sentence as rule as structural English standard but also important in conveying messages to the readers. It means that if a writer ignores the rules in constructing sentences, s/he would make error to convey the important information to the readers. From the reasons, it is interested to carry out a research about grammatical errors in thesis proposal made by EFL learners of STIBA Persada Bunda. Proposal research paper was chosen because it was made by students who had completed all writing class and other supplementary lecture to support it. Furthermore, thesis is the reflection of the students' achievement of English during their college study.

Based on the several explanations mentioned, the purposes of the research were:

1. To identify the types of error made by eight semester students of STIBA Persada Bunda in thesis proposal.

2. To identify the cause of error made by eight semester studetns of STIBA Persada Bunda in thesis proposal.

Academically, the result of the research was very significant for the students in order to be aware of potential error they are likely made in learning grammar. Furthermore, the result of this research was expected to give valuable contribution for the lecturers as well as the teachers to improve and innovate their teaching learning quality. For other researcher, the result of the study can be used as reference for starting point to conduct further study about teaching and learning grammar and writing.

\section{The Concept of Error}

According to Richard et al in Kusumawardahni (2017:85) an error is a grammar deviation of a native speaker which reflecting the learners' interlingual competence. Moreover, Harmer in Tandikombong, Atmowardoyo, and Weda (2015:4) asserts that error as a stage of students' Interlingua development which continuously reshapes to achieve the full mastery. It means that error is a sign of students' progress in learning L2. Furthermore, Dulay, Burt, and Krashen (cited in Ahmad 2014: 13) defined errors as the deviation of learner speech or writing from several selected norm of Standard English. From the several ideas, it can be inferred that error is a deviation from Standard English which is considered as a signal to achieved target language competence.

In contrast, mistakes were carelessness in performance because the learners slip to apply what she or he had already known. Ellis (2014:17) underlined the difference between errors and mistakes. In his opinion, errors are occurred because the learners had the wrong concept about a specific grammar. They do not realized in making errors; even they do not know how to correct it. But, mistakes occurred because of learners' carelessness. It can be said that the learners actually had the competence in such performance, but they slip and do the incorrect one. In short, it can be implied that error is a competence error where the learners did not know the correct one but the mistake is only slips, and the learners know how to correct it. 
Error analysis is very useful for teachers or lecturer to measure learners' competence in target language, especially for second or foreign language learners. According Yang (2010:266) error analysis is the process of determining the incidence, nature, causes and consequences of unsuccessful language. It has a significant role in language learning because it is the sign that a language learner does master the rules of the target language effectively. Moreover, Sukardi in Tandikombong, Atmowardoyo, and Weda (2015:4) stated that error analysis is an attempt to describe errors found in writing and speaking. From the previous statement it can be inferred that errors analysis is the analysis of linguistic which concerned to the errors learners make.

According Dulay, Burt, and Krashen (cited in Ahmad 2014: 13) classified error into four levels. They were errors in linguistic taxonomy, surface strategy taxonomy, comparative analysis taxonomy, and communicative effect taxonomy. Errors in surface strategy taxonomy were used to analyze quantitative data. Furthermore, they classified Surface strategy taxonomy which concerned with the use of surface structure. Into omission, addition, misformation and misordering.

Omission is error which indicated by the missing of an item which should be appeared in a sentence. In Standard English, morpheme was divided into two classes: content words and grammatical words. Content words are words with sentence referential meaning such as nouns, verbs, adjectives, adverbs, etc. Grammatical or function words are words with little function in delivering the meaning in a sentence. It usually consist of noun and verb inflection (-s, ed, ing): the article (a, the, an): verb auxiliries (is, will, can, may, etc); and preposition (in, on, or, etc). Commonly EFL learners delete grammatical morphemes more frequently than content words. Content words deletions are usually lead by limited vocabulary. For example : She is student. In the sentence, the word $a$ is omitted from the sentence.

Addition errors are identified by the appearance of an item which must not appear in a standard English sentence (Dulay, Burt, and Krashen cited in Ahmad 2014: 13). They added three types of addition errors. First, double markings which identified by the failure to omit one item which are needed in some linguistic construction. For example: Susi didn't saw $m e$. In the sentence double marking of past tense occurred in the word didn't and saw. The correct sentence should be: Susi didn't see me. Second, regularization which indicated by a marker which is added to a linguistic item. It is also indicated by addition to items of the given class which should not take a marker. For example : teeths instead of teeth. Regularization error also occurred because of irregular plural marker. Third, simple addition which is indicated by all errors in addition types. Whenever addition occurred but it do not include in double marking and regularization, it belong to simple addition. For example: the bears doesn't live in the cave. There is simple addition that should be the bear doesn't live in cave.

Misformation is error which occurred because of the incorrect form of a morpheme or structure. Misformation categorized into three types. First, regularization errors that falls under the misformation category. This error is caused by giving regular marker for the irregular one. For example: the words go changed into goed instead of went. Second, Archi-forms 
errors which indicated by the incorrect selection of a class in forming to represent others. For example: I greeted him last week. His talk with my sister. There is archiforms error occurred in the word his that should be he talks. Third, alternating forms error which indicated by the learners' limited vocabulary and grammar mastery. For example: I gone to the beach yesterday. In the sentence, the alternating error occurred in the word gone that should be went.

Misordering is error which caused by misplacing a morpheme or a group of morphemes in a sentence. For example: They don't know where are you. Misordering occurred to the sentence which should be They don't know where you are.

\section{The Cause of Error}

According Richard cited in Kusumawardhani (2017:86), there are causes of errors: (1) Inter-lingual. It is related to first language influence, this is a cause of errors by interference of the learner's first language (2) Intra-lingual. It related to their learning strategy such as incorrect analogy, incorrect analysis, incomplete structure application, redundancy, co-occurrence restriction, hypercorrection, and overgeneralization. It reflects the learners' ability in specific stage and illustrates characteristics of language acquisition. (3) Communication strategy-based error. It is related to error which caused by interlocking definition to express meaning in target language. The errors tent to happen when they tried to solve their problems, and avoided something which they do not understand. (4) Induced errors. These errors are caused by misconception with teachers' definitions, examples, explanations, and exercise. The errors happened in teaching and learning process.
In line with this point, Brown cited in Sari (2018:129) underlined two similar points of the causes of errors. He assumed four causes of errors; first, interference transfer of first language. Second, Intralingual transfer: from structure of first language. Third, learning context which is skipped in both of transfer fourth, communication strategy which occurred in expressing idea when linguistic forms are unavailable.

The causes of errors proposed by Richard in Kusumawardhani (2017:86) was applied to find out the cause of error in this research. They are:

1. Inter-lingual (mother tongue error): this kind of error is influenced by first language which interferes with target language.

2. Intra-lingual errors: this types of errors due to target language itself such as (a) incorrect analogy, (b) incorrect analysis where learner made inaccurate hypothesis, (c) Applying incomplete structure, (d) redundancy exploitation, (e) fail to notice the exceptional structure, (f) Hypercorrection (g) fail to generalize or simplification system where error due to the unappropriate of words usage or structure

3. Communication strategy-based errors which which caused by interlocking defenition to express meaning in target language. The errors tent to happen when they tried to solve their problems, and avoided something which they do not understand.

4. Induced errors are caused by students' misconception with teachers' definitions, examples, explanations, and exercise. The errors mostly happened in classroom activity. Induced error in teaching learning activity covered material, teachers' explanation, and pedagogical competence. 


\section{The Concept of Grammar}

According to Harmer cited in Haryanti, Sucipto, and Makmur (2017:84) underlined that grammar is the illustration how the words transformed into another form and grouped together into sentences. In line with this point, Nelson in Tandikombong, Atmowardoyo, and Weda (2015:5) asserts that grammar is a pattern to combine words in a language into greater units. From the several ideas, it can be inferred that grammar is a pattern to make sentences into greater unit.

\section{The Concept of Writing}

Writing is an activity in building, enable learners to create imagination of their own world (Halliday cited in Gusparia, 2014:35). Furthermore, Negari (2011: 300) assert that writing associated with choice of words or diction, the use of correct grammar, syntax, mechanics, and organization. In using correct grammar, a writer should consider with the agreement of subject and verb, tense, and article use. Besides the mechanics, the writer also should consider punctuation, spelling, and handwriting which are important in writing. The last aspect of writing is organization. It means that the writer has to organize ideas into a coherence and cohesive form.

From the idea, it can be said if writing as a conscious activity to produce language which derives from the mind. Through writing, learners can express their ideas or thought. To compose a good writing, there are some aspects to be applied in writing a composition such as structure, mechanics, and organization.

\section{METHOD}

It was descriptive research which aimed to identify the grammatical error made by EFL learners of STIBA Persada Bunda in thesis proposal. Best cited in Maspufah (2018: 74) said that descriptive research describes the condition or thing which occurred at the same moment of the study. In other words descriptive research does not intend to find a new theory, it merely tries to verify and describe the existing one. By implementing quantitative approach, it attempt to find out grammatical error made by eight semester students of STIBA Persada Bunda in thesis proposal.

The research was conducted at STIBA Persada Bunda Pekanbaru, Jalan Diponegoro number 42 Pekanbaru. Thirteen students from eight semesters of eight semester students of 2018/ 2019 of STIBA Persada Bunda. were taken as the sample of the research.

There were two data used in this research: quantitative and qualitative data. The students' thesis proposals made by eight semester student at 2018/2019 academic year. taken for quantitative data. While, the interview was taken for qualitative data which used to support the quantitative data. ear. The thesis proposal were collected from eight semester students of class A which consisted of 13 students. The qualitative data in the form interview were conducted after the researcher finished analyzing the quantitative data.

In analyzing the data, two raters were collaborated in making judgement dealing with grammatical errors in students' thesis proposal. They were the lecturers in STIBA Persada Bunda Pekanbaru.

The grammatical error in students' thesis proposal was described by following several steps. First, the errors from the background of the research of the thesis 
proposal which placed in chapter 1 was identified. The sentences which indicated contain error were underlined and highlighted. Second, the errors were defined and classified into its type. After identified and classified the errors, the list of error was made to display the percentage on chart. The data were presented in percentage to find out the most frequent error made by students in thesis proposal. The data were also displayed in a chart to see the rate of each type of error found in students' thesis proposal. The formula used to find out the percentage as as stated by

Arikunto cited in Ahmad(2014:36) as the following:

$$
F S=\frac{S}{N} \times 100 \%
$$

Where: FS = The percentage of error

$\mathrm{S}=$ The errors in each item

$\mathrm{N}=$ The total number of item

The interview were analyzed in several steps. The first, the data from interview were recorded. Second, it was converted into written form or transcript. Then, the transcript was condensed and compressed to be more understandable. Next, the data were categorized and interpreted to answer the research question. Finally, the interview can be interpreted to find out the most frequent and the cause of error.

\section{FINDINGS AND DISCUSSION}

\section{The Types of Students' Grammatical Error}

The data were analyzed by using surface strategy taxonomy. The data were classified based on its type of error: addition, omission, misformation, and misordering error. These errors defined as mechanics (spelling and punctuation), grammar, and word choices. Then, the error was presented in percentage to see the most frequent error occurred in thesis proposal. The data were presented as the following:

Table 1.1 Errors on Surface Strategy Taxonomy

\begin{tabular}{llcc}
\hline $\begin{array}{l}\text { Surface } \\
\text { Strategy } \\
\text { Taxonomy }\end{array}$ & Component & $\begin{array}{l}\text { Freq } \\
\text { uency }\end{array}$ & $\begin{array}{l}\text { Percen } \\
\text { tage }\end{array}$ \\
\hline $\begin{array}{l}\text { Omission } \\
\text { Addition }\end{array}$ & $\begin{array}{l}\text { Double } \\
\text { Marking }\end{array}$ & 23 & $11 \%$ \\
& $\begin{array}{l}\text { Simple } \\
\text { Addition }\end{array}$ & 25 & $12 \%$ \\
& & & \\
Misforma & Regularization & 4 & $2 \%$ \\
tion & $\begin{array}{l}\text { Archi-form } \\
\text { Alternating- } \\
\text { form }\end{array}$ & 41 & $20 \%$ \\
Misordering & 86 & $41 \%$ \\
& & 4 & $2 \%$ \\
\hline \multicolumn{2}{c}{ TOTAL } & 207 & $100 \%$ \\
\hline
\end{tabular}

The distribution of the grammatical error as following:

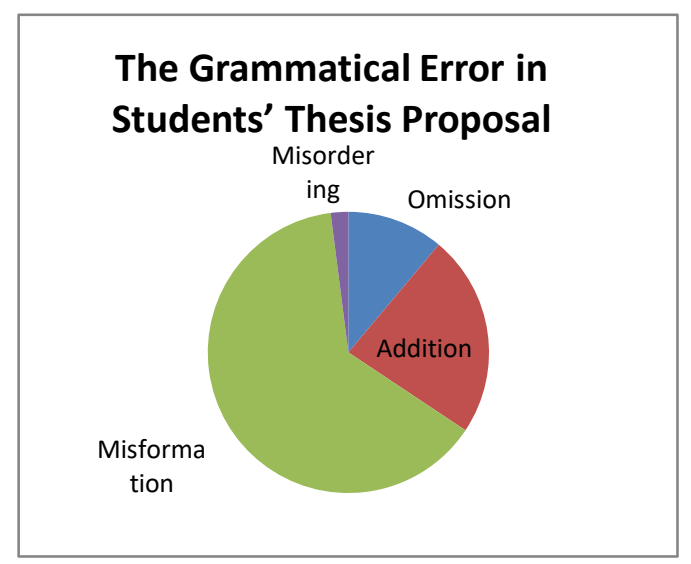

Figure 1.1 Students' error distribution 
From the data was found out that misformation is the highest error occurred in thesis proposal. There were 131 out of 207 error or $63 \%$. The highest percentage of misformation error was alternating form error. There were 86 error or $41 \%$ Misformation is the use of the incorrect form of a morpheme or grammar. It was caused by leaners' vocabulary and grammar. For example:

(1) a. This type of presupposition has $\varnothing$ assumed to be true.

b. This type of preposition has been assumed to be true.

(2) a. She even said that her soul will $\varnothing$ killed and buried.

b. She even said that her soul would be killed and buried.

Some students were error in forming passive sentence. According to Azar in Ahmad (2014:117) in forming passive sentence, the subject was switched to be object and the object was also switched to be subject. Next, the verb be inserted after subject. Then, the verb should be in past participle form. Intransitive verbs could not form into passive sentence. However, some students violated the rule by omitting the verb be or letting the verb in present form. Students also made error in word choice.

(3) a. .... several characteristics; kind, never get angry, always happy, etc

b. ..... several characteristics; kind, patient, cheerful, etc

Using appropriate diction in Standard English is very important composing writing. But, some students tent to use inappropriate diction as they had limited understanding on word choice. It was similar with the result of research conducted by Hamzah (2012). He found error in choice of word, group of verb, article, preposition, pluralism and spelling. In short, it could be said that misformation error occurred in word choice and violating the grammatical rule this research.

The second highest error was addition. Addition is the presence of an item which must not appear in a Standard English. For example:

(4) a. The written language can be analyzed from the quotation mark, which is as the sign of the utterance .....

b. The written language can be analyzed from the quotation mark, which is the sign of the utterance .....

(5) a. The sufferers would feel safe in there.

b. The sufferers would feel safe there.

The addition of unnecessary words such preposition in and of, article $a$ and the, which were dominantly used in their sentences. It was also similar with previous research conducted by Christina (2014:84). Her result showed there were 3 types of grammatical errors in using article in speaking in the form of omission, addition, and misformation.

The students also made error in double marking addition. Double marking addition is the failure to omit one item which needed in some linguistic construction. For example:

(6) a. Citizen who come from rich family usually always think about image and power 
b. Citizen who come from rich family usually think about image and power.

(7) a. She did not allowed her husband to...

b. She did not allow her husband to...

Double marking error was also made to express their idea. The dominant double marker addition was the use of grammar, especially the tense marker.

Omission was the third highest number occurring error in students' thesis proposal. It was 23 errors or $11 \%$ out of all errors. Omission is error which indicated by the missing of an item which should be appeared in a sentence. For example:

(8) a. Most of us can not realize that is $\varnothing$ mental disorder.

b. Most of us do not realize if it is a mental disorder.

(9) a. She is afraid $\varnothing$ getting close to the men, except her brother.

b. She is afraid of getting close to the men, except her brother.

The result of the research was similar with Kusumawardhani's research (2017). She found that 6 types omission: auxiliary, articles, countable and uncountable nouns, apostrophe's reposition. However, there were only three types of omission found in this research. They were noun and verb phrase, article and preposition. Some of them omitted affix $-S$ in marking plural noun, affix - ed in forming regular verb, and affix -ing in forming continuous tense and also in gerund and preposition. Students omitted article $a$, an, or the and tent to make generalization noun. Omission of preposition such as in, or, and of also occurred in students' thesis proposal.

The least frequent error found in students' thesis proposal was misordering. It was 4 errors only or $2 \%$ out of all errors. Misordering is the incorrect placement of a morpheme or group of morphemes in an utterance. For example:

(10) a. The researcher can turn out to be someone who is very different or another identity of her.

b. The researcher can turn out to be different person or her other identity.

(11) a. This is can seen from the place, the time, and the things...

b. It can be seen from the place, the time, and the things...

Misordering contributed the least error in the thesis proposal. The errors were caused by misplacing a morpheme or a group of morphemes in a sentence.

To conclude, four types of error found in eighth semester students' thesis proposal. They were addition, omission, misformation, and misordering. Addition error occurred in high frequent, while misordering was in low occurance.

\section{The Cause of Error}

Three causes of error found in students' thesis proposal. They were interlingual, intra-lingual, and communication strategy.

The first error was the effect of inter-lingual which also called mother tongue error. The error influenced greatly by first language which interferes with target language. It was indicated by first 
language grammar; in this case was the native of bahasa Indonesia, which transferred into target language. For example: (1) this is the reason why agrophobia sufferers choose to stay at home. The phrase the reason why is not appropriate with Standard English Form. The phrase was affected by her native language. It was more appropriate if the sentence was corrected to be this is the reason for agrophobia sufferers choose to stay at home. (2) ...who is very different or another identity of her. The underline phrase was affected by her native grammar which commonly put the possessive adjective at the end of the sentence. This rule was reverse with English grammar. The sentence should be corrected into: ... who is very different or her other identity. (3) The author only writes about romantic story and all of his fantasy in it. The underline words were the simple addition interfered from the native language. The student made two expressions which had similar meaning in one sentence. The sentence should be corrected by omitting in it phrase to be The author writes about romantic story and all his fantasy. The inter-lingual factor was the result of transfer from the first language to target language but they are not around with the second language system.

The inter-lingual error was also because of students' first language which influenced the translation process to target language. Based on the interview, it was found out that students arranged the idea in their first language then transfer it to target language target language. The error occurred in the process of transferring the idea from first language to target language. They were not only transferring the words but also the rule by applying words to words translation. This condition made their writing was interfered by their first language in both of grammar and sentence formation. Grammatically, first language structure is different with target language. If the students transferred the sentence by using first language structure to target language, it had violated the target language structure and producing error. It is reasonable because the interfere of first language is the major problem in learning target language (Yang, 2010:267).

The second, there were many errors which influenced by intra lingual errors in this research. Intra lingual error was caused by the target language such as incorrect analogy, incorrect analysis where learner made inaccurate hypothesis, applying incomplete structure, redundancy exploitation, fail to notice the exceptional structure, Hypercorrection and fail to generalize or simplification system For example: (1) They selected to choose everything to wear. The underline words selected to choose contain redundancy meaning. It should be They selected everything to wear. (2) They are very need money. The sentence state in active form, but it was misformation error because the verb be are followed by a verb. While in active sentence the verb be should be followed by an adjective or a noun. So, the sentence should be: They need money. (3) This phenomenon have already happened around the world. The sentence's subject of the sentence was singular, so the verb should be given $-\mathrm{s}$ /-es. The sentence should be This phenomenon has already happened around the world. (4) She did not allowed her husband to leaved. The sentence was in active statement with two double past tense markers: the word did and allowed. In a sentence only one tense marker is allowed. Moreover, the word leave should not write in past tense 
because there was infinitive to, so it must be followed by infinitive. Besides that the past form of leave is left. The correct sentence should be: she did not allow her husband to leave. (5) There $\emptyset$ a comedown from drugs refers to the withdrawal symptoms. The student did not acquire the sentence pattern. For the past tense, the pattern $\mathrm{S}+$ to be (is, am, are) + noun. So, the sentence should be There is a comedown from drugs refers to the withdrawal symptoms. Briefly, it could be said that intra-lingual occurred because of the incomplete rule application, exploiting redundancy.

The first language also affected students' ability in comprehending English grammar and structure. This condition is called intra-lingual. It was indicated by the students' errors because of incomplete comprehension of English structure. Intralingual occurred in the form of redundancy and ignorance the structure. Redundancy was in both of word and clause. It meant that students chose two words which had similar meaning in one sentence, or they made a clause to explain the information which had been stated before. Ignorance of structure occurred because of first language structure transferred to target language directly which made the sentence formation violated Standard English structure. In short, It the incomplete rule application, exploiting redundancy were the factors of causing intra-lingual error.

The third, the factor was caused by communication strategy-based error. Communication strategy-based errors are the error that caused by achieving communication of encoding or expressing meaning in a language. The errors happen in trying to solve their problems, and avoidance of something they do not understand. The students were made a few errors in communication strategy error. For example: if her husband leaved the apartment. The student tried to form the past form of the word leave by adding affix-d as regular verb. It was incorrect because the verb leave was the irregular one. Students made errors in their attempt to solve their problems. Some of them even avoided some words which they did not understand. Based on the interview, it was revealed that all students faced difficulties in composing the thesis proposal. The following was the result of students' interview in their effort to solve the problem.

Interviewer: Do you have problem in expressing your idea in your thesis proposal? How do you overcome the problem?

Student 1: I have a big problem am. I find the synonym to make it easier mam.

Student 3: I face some difficulties. I try to overcome it by simplified my idea and find the synonym to express it.

From the interview, it could be inferred that the communication strategybased error was occurred in form of avoidance. Besides avoidance in expressing idea, students also simplified the tense used. It could be seen that most of their thesis proposal were written in present tense instead of perfect tense. So, it can be concluded that avoidance as one of communication based error occurred in students' thesis proposal.

Students' error was caused by communication strategy-based error in the form of avoidance. Schracter cited in Khansir (2012:1030) revealed avoidance as one factor in communication strategy. Students avoided difficulties in 
constructing sentence and tend to use the simpler structure. That is why most of the students' thesis proposal used present tense instead of perfect tense

It could be summed up that there were three causes of error found in this research. They were inter-lingual, intralingual, and communication strategy-based error. The inter-lingual was caused by first language interfere. The intra-lingual was caused by the incomplete rule application, redundancy exploitation. Communication strategy-based error was caused by avoidance

To solve this problem, the lecturers were intended to improve and develop their teaching technique, especially about grammar and writing. The students were also suggested to pay more attention in learning grammar, so they can be aware of potential error which they were likely made in writing. Besides that, it is suggested to students to write their idea directly in English, so they do not have to translate and transfer the first language rule to target language which causing error.

\section{CONCLUSION}

There were four types of error found in this research. They were addition, omission, misformation, and misordering. Misformation error occurred due to students' problem in choice of choice and structure. Addition error occurred because of double marking, misplacement of article and preposition in the place where it should not be. Omission occurred due to deletion of Noun and Verb phrase, article, and preposition from the place where it should be. Misordering occurred due to the incorect placement a group of morpheme in students' thesis proposal.

There were three causes of error in this research. They were inter-lingual, intra-lingual, and communication strategybased error. Inter-lingual occurred when students transferring from first language to target language. Intra-lingual occurred in the incomplete rule application, exploiting redundancy. Avoidance caused communication strategy-based error.

\section{BIBLIOGRAPHY}

Ahmad, A.M (2014). Syntactic Errors made by the Grade XI IPA 1 Students of SMAN 1 Bangkinang in Writing Report Text. Padang: State University of Padang, Unpublished Thesis

Christina, D. Ansyar, M. and Radjab, D (2014). A Study of Grammatical and Mechanical Errors in Students' Recount Text on the Second Year Students of SMPIT Sabbihisma Padang. Journal English Language Teaching (ELT) Vol.2 No.1:73-87

Ellis, Rod (2014). Second Language Acquisition. Oxford : Oxford University Press.

Gusparia, Zainil, Refnaldi (2014). Improving Students' Writing Skill of Narrative Text by Using Animation Video at Grade XI Science 2 Program of SMA N 1 Teluk Kuantan. Journal English Language Teaching (ELT) Vol.2 No.2:35-40

Hamzah (2012). An Analysis of the written Grammatical Errors produced by Freshment Students in English Writing. Lingua Didaktika. Vol.6 No.1: 17-25

Heryanti, R. Sucipto, M.H, and Makmur (2017). The Analysis of Common Grammatical Errors in Writing Narrative Essay of English Study Program Students at Jambi 
University. Jurnal Pendidikan dan Pengajaran. Vol.4 No.2:83-92

Khansir, A.A (2012). Error Analysis and Second Language Acquisition.

Theory and Practice in Language Study. Vol.2 No.5:1027-1032

Kusumawardhani. P. (2017). The Analysis of Errors Omission in English Narrative Composition Made by EFL Learner. Jurnal of English and Edication. Vol.3 No. 2 : 84-96

Maspufah, (2018). Analysis of Discourse Deixis in EFL Learners of STIBA Persada Bunda. ELT-Lectura, Vol 5 No.1:72-77

https://doi.org/10.31849/eltlectura.v5i1.1534

Negari, G.M. (2011). A Study of EFL Learners' Writing Skill. Intenational Journal of English Linguistics. Vol. 1 No.2:299-307.

Sari, R.A. (2018). Students' Grammatical Error in Speaking. Jurnal Pendidikan dan Pengajaran. Vol.5 No.2: 127137

Tandikombong,M., Atmawardoyo, H., Weda, S (2016). Grammatical Error in the English Translation made by the students of English Study Program of UKI Toraja. ELT World Wide. Vol.3 No.1:1-15

Yang, W (2010). A tentative analysis of errors in language learning and use. Journal of Language Teaching and Research. Vol. 1 No.3: 266-268. 